\title{
Corporate Social Responsibility in Pakistan: A Legal Perspective with Reference to MNEs
}

\author{
Shuhong Yu ${ }^{1}$, Malik Zia-ud-Din ${ }^{1}$, Roy Dilawer ${ }^{1} \&$ Xiaohui Ban ${ }^{1}$ \\ ${ }^{1}$ School of Law, Wuhan University, Wuhan, China \\ Correspondence: Xiaohui Ban. E-mail: wizardban@whu.edu.cn; Roy Dilawer, School of Law, Wuhan University, \\ Wuhan, China. E-mail: roydilawer@gmail.com
}

Received: June 26, 2019

doi:10.5539/jpl.v12n3p87
Accepted: July 30, 2019 Online Published: August 14, 2019

URL: https://doi.org/10.5539/jpl.v12n3p87

Acknowledgement: Research for this article was supported by The Humanities and Social Sciences Youth Fund of the Ministry of Education (Project No. 17YJC820001)

\begin{abstract}
It is no secret that many multinational enterprises have annual revenues higher than that of the GDP of a significant number of less developed countries put together. This fact puts them in a position not only to influence the host country's policies and but also lives of the people. With the rise of Multi-National Enterprises and foreign investments, the concept of Corporate Social Responsibility, theoretically a self-regulatory mechanism to ensure the active participation of corporations for betterment of society in general, has gained importance in International Law. Given the fact that a huge capital is flowing in Pakistan, it is significant to understand and evaluate the extent to which the principles of CSR are being followed in Pakistan, with a special reference to foreign investment. High ratio of Foreign Direct Investment to the annual budget of Pakistan in recent years coupled with the fact that CSR is still relatively a new concept in Pakistan amplifies the importance of CSR in Pakistan in relation to Foreign Investments. Since CSR, as per OECD guidelines, requires the international corporations to take certain measures to ensure the betterment of the locality and community, the research shall attempt to find out whether the foreign companies working in Pakistan are complying with the norms of CSR and if they do, to what extent those principles are being followed. To do that, we shall try to understand the concept of CSR, to trace down its origins, and to study its elements and key drivers. Moreover, the impacts of compliance of CSR especially on the people, environment and goals of sustainable development shall also be taken into account. The study shall try to search relevant laws, rules, regulations and guidelines, both in international and domestic legal skeletons, which emphasize the significance of CSR and its implementation. We shall try to find out whether any legal recourse or remedies are available to the people and the State of Pakistan in case foreign MNEs do not implement the CSR regulations.
\end{abstract}

Keywords: corporate social responsibility, legal perspective, Pakistan

\section{Introduction}

In modern days, the rise of multi-national enterprises (MNEs) has impacted lives of people around the globe in one way or the other. Over the years, the concept of free trade paired with the low budget of under developed countries has provided the MNEs space to move into these countries and set up their businesses. With their annual returns sometimes more than overall budget of the respective countries or at least equivalent, they have substantial ground not only to affect the policies of the government but also the lives of the people (Bantekas 2004). Earlier, such MNEs used to claim immunity behind the stated 'veil' asserting that addressees and bearers of human rights, labor, and environmental obligations under traditional treaty and customary law have been states. However, with the concept of Corporate Social Responsibility taking its firm roots around the globe, it is now difficult for MNEs to hide behind such umbrellas (Ibid:312).

Recently, the concept of CSR, theoretically a self-regulatory mechanism to ensure the active participation of corporations for betterment of society in general (Alavi, Babek et al. 2016), has gained importance in International Law as mentioned in preceding paragraph. This study will delve into details of the concept of CSR, its origin, its significance and related instruments in International Law which is a developing field. It will discuss 
the OECD Guidelines for MNEs (Gordon 2001), ILO Regulations, WTO Regulations, some Bilateral Investment Treaties, and the UN Norms on the Responsibilities of Transnational Corporations ${ }^{1}$ etc. Once having established the existence and importance of CSR and also the fact that investment does not come alone; it is always accompanied with CSR, the study shall move to the main topic- legal perspective of CSR in Pakistan.

Given the fact that a huge capital is flowing in Pakistan (BOI 2018), this study will try to evaluate the extent to which the principles of CSR are being followed in Pakistan There are two significant reasons for considering the case of CSR being followed or not in Pakistan, and legal structure of CSR; 1) the legal structure and awareness about CSR at public, corporate and governmental level is apparently non-existent and 2) the sheer volume of Foreign Investment in Pakistan when compared with the budget of the country demands an extensive research in this field. Moreover, our special focus amongst Foreign Enterprises shall lay upon Chinese Corporates working in the Pakistan and the reason for that is also two-folded i.e. 1) the investment of China in Pakistan, not only because of recently concluded agreements but also owing to long standing relations between these countries, is not a transient one, and is expected to move from this generation to at least next generation, and 2) the sheer volume of Chinese Investment in Pakistan when compared with all the other foreign investments combined does beckon a special focus on Chinese Investment.

As mentioned before, the investment flowing in the country coupled with the fact that CSR is still relatively a new concept in Pakistan intensifies the connotation of this study. Through this study, we shall try to understand what CSR as a concept is and what it signifies and includes. We shall look at the basis and foundation of CSR in international legal regime. We shall also focus on the requirements under Pakistan's domestic legislation upon corporate operating in Pakistan to follow CSR. Since CSR, as per OECD guidelines, requires the international corporations to take certain measures to ensure the betterment of the locality and community, the research shall attempt to find out whether the foreign companies working in Pakistan are complying with the norms of CSR and if they do, to what extent those principles are being followed. Moreover, the impacts of compliance of CSR especially on the people, environment and goals of sustainable developments shall also be taken into account. We shall also research on the legal cases, if any, related to CSR to find out the legal remedies that people of Pakistan can avail to enforce provisions and standards of CSR. To conclude the study, certain recommendations or suggestion if deemed necessary shall also be put forward in addition to the conclusion.

The study is divided into five parts. Part I shall introduce, define and understand the concept of CSR, and shall discuss its evolution, elements, drivers and growth of CSR in Pakistan to have a basic understanding of the subject-matter under study. Part II will be discusses the legal aspects of CSR wherein we shall first talk about the International instruments and guidelines about CSR. Afterwards, we shall focus on the legal basis of CSR in Pakistan and we shall also discuss a court case related to CSR activities of MNEs. This part will be instrumental in making our legal basis about the topic. Part IV of this study is dedicated to analysis of CSR activities of different MNEs working in Pakistan which will give us an overview of how Corporations in Pakistan are following CSR and in what areas their focus lie mostly. It will also help us evaluate whether they carry out CSR activity as a responsibility or as philanthropic work. Part V of the study conducts an analysis of what we would have discuss in the sections before. We shall precisely and summarily revise the problems and obstacles that Pakistan face in proper implementation of CSR. In the second half of that part, our focus shall move to the solutions of the problems which we would have found and stated in the first half of the part. The last part shall conclude the study by providing a brief summary of the study and its finding.

\section{Theoretical Foundation of the Study}

In this part, we shall aim to study the general concepts of CSR as they exist in theory because without understanding the exact definition, historical evolution and development of CSR and its origins, its elements and constituents, its drivers and its growth within Pakistan, it shall be extremely naïve and inappropriate to study make a comprehensive and logical study of CSR in Pakistan. So, we are going to discuss mainly five topics in this part which are given below.

\subsection{Corporate Social Responsibility Defined}

For most part of previous century, CSR was never defined; in fact, it never existed. CSR was preceded by Corporate Philanthropy in which corporations used to give charities and do some social welfare projects to generate goodwill and promote their business. The CSR concept evolution started when the society became more and more concerned about the damages created by businesses on environment and society (Waheed 2005). Many events over the last decades shaped the current form of CSR and thus the concept was defined in more absolute

\footnotetext{
${ }^{1}$ Norms on the Responsibilities of Transnational Corporations and Other Business Enterprises with Regard to Human Rights, 2003
} 
terms. CSR does not have a single unified definition and thus has several definitions depending on the contexts it is defined. To move forward we need to look at some of the definitions given in various texts.

The broader definitions of CSR are concerned with what is or what should be the relationship between global corporations, governments of the countries and individual citizens. However, to get a general idea and to review them afterwards, this paper has selected some of the definitions according to the context of this paper.

CSR has been defined as the integration by enterprises on a voluntary basis of the social and ecological concerns in their business transactions and their relations with the involved partners (Ibid:7). As per another definition, CSR is actually a concept to achieve success in business such that moral and ethical values are respected while people, societies and the natural environment is respected ${ }^{2}$ whereas CSR is termed as the organizations social license to operate, and is important to legitimize business activity, particularly in the global activity where businesses are accused of practicing soulless capitalism in another description.

A glance over the above given definitions sets out one thing for sure- CSR involves a practice of showing a practical concern for social and environmental impacts of running a business. When we talk about social impact of a business or corporation, it entails a whole spectrum of aspects from labor rights, human rights, education, workplace safety etc. Similarly, the environmental impacts include a wide range of facets which considers not only contemporary concerns but also prospective matters of sustainable development.

Recent definitions also show that CSR, despite being a self-regulated mechanism, extends much beyond the normal random acts of philanthropy so that compliance of information sharing, open disclosure, labor standards, customer sensitivity etc. is achieved by corporations. However, coming up with a hard and fast definition of CSR is practically impossible as well as theoretically undesired, because CSR is not a stagnant concept; rather it is an ever-evolving practice which is to be updated with changing times and thus, demands. The words of John Zinkin of Nottingham University attest this fact in this way, "defining responsible behavior and getting CSR right is difficult because it is a journey, not a destination. As countries evolve, getting richer and better educated, so society's expectations of company behavior become more demanding. So what was good enough yesterday may no longer be good enough today, and certainly will not be good enough tomorrow." (Williams and Zinkin 2010).

\subsection{Historical Evolution of CSR}

The concept of CSR is not historical and has evolved a great deal recently in the past three decades or so. For a good part of $20^{\text {th }}$ century, the concept remained stagnant because MNEs were never recognized as addressees of international law. MNEs always tried to hide behind the umbrella of states, as states were deemed to be addressees and bearers of human rights, labor and environmental obligations under traditional treaty and customary international law (Bantekas 2004). The courts of the country of the parent company's incorporation refused to entertain suits pertaining to operations of the subsidiary in the host state, especially based on forum non convenience ${ }^{3}$ in recent cases (Muchlinski 2001). However, this immunity no longer lived through the turn of century where because of different factors, discussed below, the corporations, reluctantly though, stopped to hide behind state veil.

The corporations have previously never felt that they were responsible to the society for their activities and businesses. However, the $20^{\text {th }}$ century saw a marked shift from that traditional approach. It is pertinent to mention here that over the past 20 years, (MNEs) have made important changes to their CSR policy. This shift in policies owes a great deal to changing societal values and consumer demand for corporations to be on the right side of social justice issues and be good stewards of the environment (Cochran 2007). Nowadays, companies have begun approaching CSR in a more strategic way, recognizing that aligning these projects with their business model and goals can effectively improve a company's competitive advantage.

The historical evolution of CSR can be summed up in following stages. Initially there was a built-up of societal pressure against the Governments and corporations to be held accountable for the harms they do to the environment and society. During this phase in 1960s, Friends of Earth was founded and first Earth Day was celebrated in USA (Waheed 2005). In the last two decades of previous century, wide corruption, labor and human rights violations were reported across the globe which raised the concerns among the society about the activities of major corporations and thus a pronounced form of CSR started to shape. It was also during this period that negative impacts of these businesses on environment were properly understood and thus certain milestones

\footnotetext{
${ }^{2}$ Defined by the official website of 'Business for Social Responsibility' which is a global nonprofit organization that works with its network of more than 250 member companies and other partners to build a just and sustainable world. (https://www.bsr.org/en/)

${ }^{3}$ Forum Non Conveniens is a court's discretionary power to decline to exercise its jurisdiction where another court may more conveniently hear a case.
} 
(Gordon 2001) were achieved during this era. The modern form of CSR as it exists today is result of efforts done in previous century coupled with steps taken in this one. This phase is also marred with certain disasters, (Petrick and Scherer 2003) and several treaties and guidelines ${ }^{4}$ were reached to address the issues of labor and human rights and environment. This last phase is significant not only because of its proximity but also due to globalization, security threats ${ }^{5}$, and realization of common destiny among states.

CSR is thus a dynamic concept as mentioned above. In a perpetually changing world, there is a constant re-evaluation of what CSR means, individually and collectively, within business, for government, for societies in which business operates and for the environment (Waheed 2005).

\subsection{Elements of Corporate Social Responsibility}

The total social responsibility of the business is composed of different components that are combined to form one whole concept. For this paper, we have divided CSR into four basic elements which are Philanthropic Responsibilities, Ethical Responsibilities, Legal Responsibilities, and Economic Responsibilities. We shall briefly explain these elements of CSR in following paragraphs.

\subsubsection{Philanthropic Responsibilities}

Philanthropic Responsibilities of a company are voluntary contributions done by company for the welfare of the society and environment, and is the old form of CSR or predecessor of CSR. Philanthropic Responsibility therefore is related to corporations' charity work which they do to improve the communities in the localities (Ahmed and Ahmad 2011). This is done so that the corporations can compensate for resources they extract or to reimburse any imbalances or losses in ecosystem due to their extractive activities, exploitation of resources natural and human. No one expects or requires them to do it morally and/or legally, but they do it as a voluntary participation in a charitable manner to uplift the society's standard of life and quality of life (Hameed 2010). Since philanthropic responsibility is entirely voluntary in nature, there is practically no limit and no requirement as to what extent should a company does philanthropic CSR. Mostly to earn good will among society, philanthropic CSR is incorporated in the strategy of a company.

\subsubsection{Ethical Responsibilities}

The companies are also expected to follow the ethical and moral norms of the society. Usually it is to adhere to expectations to do certain acts, and refrain from doing those acts which society prohibits to do. In other words, fulfilling ethical element of CSR means to show a respect for moral norms of the society.

\subsubsection{Legal Responsibilities}

Legal responsibility is related to ethics which are codified into laws. These laws require corporations to provide goods and services that at least meet minimal legal requirements and standards of industry. It further binds companies to perform consistently as law of land and government expect from corporations (Ahmed and Ahmad 2011). In other words, obeying state rules and regulations while running business is termed as legal responsibility. The legal responsibilities of the business reflect the business operations according to the laws and regulations (Hameed 2010).

\subsubsection{Economic Responsibilities}

The fourth element of CSR is economic responsibility which each company or corporations owes to its shareholders and owners. It relates to maximizing profits and maintaining high level of efficiency in its operations. It is directly related to the owners and shareholders so that they can get maximum monetary benefit from their investment. So, these are the elements of CSR which an ideal company in this context is deemed to possess thereby implying that a socially responsible company tries to maximize its profit, to behave and act in accordance with the ethics and norms of the society, to follow the law of the land, and to act as a good corporate personality by voluntary contributing to the welfare of society and protection of environment.

\subsection{Key Drivers of Corporate Social Responsibility}

In this heading, we would try to find out the forces which push companies to implement CSR. There are many factors and stimulus for a company to pursue a strategy of CSR while doing its business in a certain area. They range from voluntary to forced, abstract to material, monetary to social, legal to moral etc. We will try to discuss some main factors which have pronounced the concept of CSR in practical form in recent years.

\footnotetext{
${ }^{4}$ World Social Forum held- the WEF's failure 2000; World Summit on Sustainable Development, USA 2002; UN Norms on the Responsibilities of Transnational Corporations and other Business Enterprises with regard to Human Rights 2003; Paris Accords 2015

5 9/11 Attacks on World Trade Center, New York in 2001; London Attacks, 2005; Rise of IISIL and other terrorist organizations.
} 


\subsubsection{Stability of Corporations}

One of the key drivers of CSR is stability and affluence of companies. With companies becoming more and more affluent, stable and grown-up, they tend to engage in CSR more often than those which are not. The reason is quite simple- no one would consider doing these voluntary acts when basic needs are in question.

\subsubsection{Responsible Behavior}

Another important driver is strategy of a company to be more responsible to the society and environment, because doing so makes them feel better corporate citizens especially in the eyes of society, and thus raises their goodwill.

\subsubsection{Public Pressure}

Public pressure through various means such as NGOs, media, state and public bodies is also pressing organizations to become more responsible socially. Over the last decade, government and political institutes have taken more keen interest in CSR and business behavior, while NGOs and media have also accentuated the call for increased sphere of CSR. This has led to legislation in some developed countries to codify the activities including CSR of a company, e.g. United Kingdom has introduced new Companies Act (2006), which requires that directors need to be aware of both the environmental and community impacts of their business operations and processes (Veronica 2017).

\subsubsection{Social Media}

Social media in last half decade has contributed considerably to the awareness of CSR where online bloggers write and discuss on such issues and which is easily accessible to different parts of the world. For example, Only in China there are more than 80 million bloggers from a large and constantly growing community of internet users engaged in online discussion about contemporary issues (Chielecki 2014).

\subsubsection{Climate Changes}

Another main driver which is now getting more importance is the concern for climate change. Over the years, the climate has been severely harmed by activities of mankind, and it continues to get worse with every passing day. There is a growing sense among corporations to save the environment from harmful impacts of their activities- however, this sense is still infant and is growing too slowly. With conferences being held and accords being reached among world leaders, the environmental concerns are likely to increase in the near future.

\subsubsection{Globalization}

Last but not the least is the impact of globalization on the growth of CSR. With CSR being more practiced in developed countries, globalization is taking it beyond the borders into less developed and under developed states. CSR (CSR) of business activity is strongly influenced by globalization, particularly through the change and erosion of national political power (Alex 2016).

\subsection{Growth of Corporate Social Responsibility in Pakistan}

For most part of its history, CSR in Pakistan has existed in the form of philanthropy and voluntary donations which owes much to its religious teachings and traditional societal norms. In Pakistani community, it is normally deemed incumbent on every individual to give a part of his earnings for charitable causes. Same is the case with companies and corporations working in Pakistan which mostly donated services and financial resources to the causes of education and health. Agha Khan Development Network conducted a survey in 1981, which revealed that donations given by individuals in Pakistan for charity stands at US $\$ 1.5$ billion $^{6}$.More than 90 percent corporate bodies were found to be involved in charities either directly giving to individuals, or philanthropy through nonprofit organizations (NPOs) and trusts/ foundations owned by the companies. However, as CSR is evolving around the globe, so is it taking shaping in Pakistan? Now SCR is being incorporated in companies' strategies as proper projects rather than just voluntary donations. The process is no doubt slower than the pace with which it is evolving in the developed world, but it is not non-existent as it might seem at first.

There are efforts on the intellectual front as well an example is the yearly report on the State of Corporate social responsibility in Pakistan. Security Exchange Commission of Pakistan has laid down guidelines to inform companies about their CSR (SECP 2003). The guidelines are periodically revisited and reports about CSR practices in Pakistan (Ahmed and Ahmad 2011) are also published. These efforts on intellectual points coupled with scholarly articles and researches have done great service to the cause of CSR in Pakistan.

\footnotetext{
${ }^{6}$ This compares favorably with the total health and education sectors government spending of US $\$ 1.8$ billion and the size of the Social Action Plan (US \$ 1.1 billion) in the years $1996-97$.
} 
In comparison to local companies, the investment and business volume of Multinational enterprises (MNEs) is colossally huge. The CSR practices are also generally found to be more pronounced and streamlined in MNEs than in local companies. Therefore, it is quite understandable that CSR of MNEs have the greatest portion in the overall CSR chart in Pakistan. However, having said that, CSR in Pakistan is relatively in premature stages, and it must go a long way.

Aymen Sajjad and Gabriel Eweje conducted a very detailed research (Sajjad and Eweje 2014) in 2014 and gave out their report on 'Corporate Social Responsibility in Pakistan: Current Trends and Future Directions' in which they investigated the concept of CSR in Pakistan by analyzing various secondary sources including extant literature on CSR, government reports, publications of international agencies, industry reports, companies' CSR/sustainability reports, and newspaper articles. They concluded that the concept of CSR is relatively underdeveloped in Pakistan. Most of the businessmen and corporations consider philanthropy as CSR and do not differentiate between the two concepts. However, only few large local companies and multinational enterprises hold a well-defined CSR policy (Ibid: 167).

While different organizations have adopted a different strategy to understand and implement CSR, however there is a lot common too between all the plans of action taken by companies for CSR. While it is often portrayed that Pakistan is a country where CSR has not yet developed properly, however there are certain companies which have taken lead in their efforts to implement CSR practices and thus their efforts must be applauded.

However, the growth of CSR in Pakistan suffered a heavy blow after a major chunk of foreign investment was halted due to terrorism threats after 9/11. However, in this decade, huge Chinese investment has recovered that loss of foreign investment in Pakistan and in last fiscal year alone, Chinese investment in Pakistan was nearly twice of investment flowing from all other countries combined. So, in following sections we shall study the CSR practices followed by some companies working in Pakistan like Zong Telecom, Huawei Pakistan, Pakistan State Oil, Unilever Pakistan etc.

\section{Existing Legal Structure of CSR}

In this part, our aim would be to find out the existing legal structure of CSR in the world in general and in Pakistan in particular. By existing legal structure, we shall try to understand what sources of CSR in International and Domestic Law exist and how they require international corporations to plan, develop and execute their CSR strategy. When we talk about sources, we mean to find out those rules, regulations, guidelines, treaties, precedents, etc. which serve as the basis of certain concept in any field i.e. in this case, CSR in International Law. However, any definition of CSR (refer to part one) would describe CSR as a set of voluntary guidelines... to achieve a balance or integration of economic, environmental and social imperatives, whilst at the same time addressing shareholder and stakeholder expectations (PCP 2006).

Since the CSR are voluntary and non-binding in character, it is ironical in some ways to expect and find out the legal skeleton of CSR. However, that does not mean that CSR is freefall concept in law i.e. unhindered by friction of law. Actually, it is imperative to note that a set of guidelines and regulations do exist for setting out, establishing, implementation and enforcement as well as to remedy and to take punitive actions where the concept of CSR is not followed partially or wholly.

\subsection{Sources of CSR in International Law}

The legal structure of CSR in International Law relies on certain legal instruments ${ }^{8}$, NGO guidelines and Code of Conducts (Bantekas 2004) which shall be discussed below in paragraphs. Over the decades, the CSR has evolved in different forms and has been reformed continuously to cover more and more areas (Ibid: 314). From a practice to gain short-term objectives and then pursuing a successful business policy, CSR has been now shaped into addressing the role of business in matters essentially within the public domain, such as poverty, labor rights, and environmental concerns (Ibid:309).

\subsubsection{OECD Guidelines}

One of the main sources which come up whenever we discuss CSR are the guidelines of Organization for Economic Co-operation and Development (OECD) which were initially adopted in 1976 and were revised periodically with the recent one done in 2011 (OECD 2011). The governments of 30 countries work together at this platform to address social, economic and environmental issues related with the MNEs and globalization

\footnotetext{
${ }^{7}$ Zong, Haier, PSO, Unilever, Jazz etc. are the companies which have clearly defined CSR policies and they implement those policies too.

${ }^{8}$ The most influential public international CSR instruments are the OECD Guidelines, the UN Global Compact, and the 1998 ILO Declaration on Fundamental Principles and Rights at Work.
} 
(OECD 2008). The OECD guidelines are a set of recommendations which have been agreed upon by the member states members of this platform which they may require MNEs working in their jurisdiction to follow for responsible business conduct. The areas covered by the guidelines include but are not limited to disclosure of reports of CSR, environment, combating bribery, consumer interests and taxation (Ibid: 10). The OECD guidelines lay down general rules about revealing and publishing the information related to company in general and CSR practices in particular, how employees should be treated, how MNEs should be made responsible to contribute to environmental managements etc. However, it is imperative to note that despite being so exhaustive and extensive, these guidelines are entirely voluntary in nature and are thus not binding on the MNEs. That must not been construed to infer that MNEs do not observe the guidelines of OECD. Though the guidelines are not implemented, however the OECD states have agreed to adhere to the Guidelines and encourage their companies to observe them wherever they operate (Bantekas 2004). Corporations for various reasons which include generating goodwill, ethics and moral conscience, expanding their business and also legal concerns of the state they operate in, tend to adhere to some degree of CSR in general.

\subsubsection{UN Global Compact}

Another significant step towards the adoption and implementation of CSR is the United Nations' initiative called UN Global Compact. The UN Global Compact, framed in 2000, is framework wherein as many as ten principles ${ }^{9}$ have been adopted by the participating countries and corporations. The areas covered by Global Compact include human rights, environmental issues, labor rights, etc. The principles call on businesses around the world to respect and protect human rights, to eliminate forced and child labor and to protect the environment by using precautionary approach. Both, OECD Guidelines and Global Compact Principles, do not entail any monitoring mechanism given the fact that they are non-binding in character. However, staying true to their nature, both are followed with a 'follow-up' mechanism wherein reports and meetings review the progress made during the past few years or so (Ibid:21).

\subsubsection{ILO Declaration}

Another instrument that we shall discuss related to CSR in International Law is the Declaration of ILO for Multinational Enterprises formally called 'Tripartite Declaration of Principles concerning Multinational Enterprises and Social Policy'. It was initially adopted by the Governing Body of the International Labour Office at its 204th Session (Geneva, November 1977), amended thrice last being at 329th (March 2017) Sessions (ILO 2017). There are several principles laid down in the Tripartite Declaration of Principles concerning Multinational Enterprises and Social Policy (MNE Declaration) which provides guidance not only to multinational enterprises but also to governments, and employers' and workers' organizations (Ibid:1). The areas in which guidelines are offered in this Declaration are employment, training, conditions of work and life, and industrial relations etc. The Declaration is not binding and uses the phrases 'encourage the positive contribution which multinational enterprises can make to economic and social progresses' and presupposes that this aim shall be realized through appropriate legislation in labor field (Ibid:2-3).

The Declaration enlists a number of areas like Employment, General Policies, Training, Conditions of Work and Life etc. and lays down regulations to be followed by MNEs. It further attaches Annex I and II wherein it has mentioned significant ILO conventions and relevant codes. Just like OECD Guidelines and Global Compact of $\mathrm{UN}$, the Declaration only has follow-up scheme as operational tool where assistance from states and corporations is key.

\subsubsection{NGO Guidelines}

The NGO Guidelines are formed by NGOs to guide businesses in their areas to be socially responsible to the locality and its people where they operate. They do not hold any force at all, but since NGOs serve as pressure groups, they do have a say and their voice does carry some weight naturally. The number of NGOs in the world is in tens of thousands, thus number of such guidelines is also uncountable.

In respect of NGO Guidelines on CSR, there is none better example than ISO 26000. A set of guidelines by the International Organization for Standardization for Social Responsibility, ISO 26000 guides on matters related to definition, identification and developing initiatives according to standardized principles of CSR (Nemoto Rechden 2013). ISO 26000 addresses seven core issues related to CSR including climate changes, labor, human and consumer rights and community involvement and development.

\footnotetext{
9 The original document included 9 principles; however, in 2004, Kofi Annan, the then Secretary General of United Nations, announced the addition of the tenth principle against corruption in accordance with the United Nations Convention Against Corruption adopted in 2003.
} 
Another specific set of NGO guidelines are found in the form of Social Accountability (SA 8000). SA 8000 standardizes 9 core areas of CSR for corporations to follow. The current version of SA 8000 covers areas such as Child Labor, Forced Labor, Health and Safety and Remuneration. SA 8000 is actually more related to Labour Rights and International Labour Organizations Conventions and national labor laws around the world.

\subsubsection{Code of Conduct}

Next Source of CSR comes from the Code of Conduct expressly laid by the corporations themselves with an apparent promise to adhere to it. These codes differ substantially from one enterprise to another and normally cover a wide range of activities from social welfare, employment standards, and labor rights to poverty alleviation, education, consumer protection and environment.

Sony Corporation's CSR reporting dates back to 1994 when they issued an environmental report (Dulbatz 2016). Sony's CSR code of conduct is aimed at achieving an increase in value through creativity and sound business practice, being fully cognizant of the fact that societies are directly impacted by the activities of the business. Sony's Code of Conduct pursues eight areas including human and labor rights, and environmental concerns (Sony Corporation 2017). In the preamble, it requires 'all Sony personnel to act in accordance with this code', and warns that 'violation of this code may result in disciplinary action up to and including discharge' (Ibid). This exhibits the dedication and commitment of Sony Corporation towards CSR activities.

\subsection{Sources of CSR in Pakistan}

As we have previously mentioned in the preceding section that the concept of CSR in Pakistan is still in its infant stage, the law itself is therefore not much defined and does not set out any specific rules to be followed by MNEs working in the country. During the 1980s and 1990s, philanthropy was the main method of doing CSR in Pakistan (PCP 2016). However, with the advent of new century, CSR rules and regulations have started to materialize into a proper shape. The process is slow because of the unsustainable market conditions prevailing in the country (Ahmed and Ahmad 2011). The legal structure of CSR in Pakistan revolves around basic labor laws corporate laws, environmental law, consumer protection laws, guidelines given by SECP and Codes and Regulations mentioned in Contract and approval.

\subsubsection{Constitution of Pakistan}

The very foremost instrument from where core concepts of CSR can be derived is the Constitution of the country. Enshrined in its various articles are the principles to abolish all forms of slavery from the country (The Constitution of Islamic Republic of Pakistan 1973 Art, 8-28). The concept of Child Labor is strongly discouraged and the Constitution prohibits the employment of children below the age of fourteen years in any factory, mine or other hazardous employment (Ibid Art. 11e). In another Article related to promotion of social justice and eradication of social evils, the Constitution requires the State to provide just and humane conditions of work, making it certain that children and women are not employed in professions unsuitable to their age or sex, and also to ensure maternity benefits for women in employment (Ibid Art. 37 e). Moreover, the rights to form Union and Associations are also guaranteed by the Constitution (Ibid Art. 17). These Articles of the Constitution ensure and promote the core principles of CSR and were also discussed in one of landmark Supreme Court Case in Pakistan. ${ }^{10}$

\subsubsection{Labor Laws}

The next element of CSR in Pakistan is covered and augmented by Labor Laws. Pakistan's labor laws have their roots in the legislation done by the British and inherited from United India at the time of partition of the Indo-Pak subcontinent (NatachaWexels-Riser 2004). In 1934, the Government enacted Factories Act which provided a break of fourteen consecutive days who had completed a twelve months service among other benefits to the worker (Factories Act 1934, Sec. 49-B). Penalties were also described in case of contravention or non-observance of rules (Ibid Sec.60) provided in the legislation which included restriction on working hours of adults, health and safety and provisions for children and adolescents. Other than this piece of legislation, Industrial Relations Ordinance, 2002, is a significant piece of legislation for the workers to form Unions, to afford and protect their rights, to provide a platform to resolve disputes between them and corporates. Section 44 of IRO 2002 allows the Government to establish as many Labor Courts as it deems necessary for the enforcement of any right guaranteed or secured by law or any award or settlement (ShuHong and Zia-ud-Din 2017).

\footnotetext{
${ }^{10}$ Const. P. 46 of 2013 Supreme Court of Pakistan, Titled Abdul Hakeem Khosa'sSuo Moto Case (PLD 2014 SC 350)
} 


\subsubsection{SECP Code of Corporate Governance}

The next part of discussion revolves around two major guidelines issued by the Securities and Exchange Commission of Pakistan (SECP). The SECP carved out Code of Corporate Governance in 2002 which was revised in 2012 wherein major portion relates to Board of Directors, their appointments, their duties, internal and external audit of the company etc. However, in the heading 'Decision making by Board of Directors', the Code requires the issues related to any significant accidents, dangerous occurrences and instances of pollution and environmental problems involving the listed company to be placed before the committee of Board of Directors. It also envisages that disputes with labor and their proposed solutions, any agreement with the labor union or collective bargaining agent and any charter of demands must also be discussed in such meetings.

\subsubsection{SECP Guidelines for CSR}

Another piece of guidelines which are by far more relevant, though not as binding as above mentioned elements ${ }^{11}$ are the CSR guidelines approved by SECP as latest as in 2013 (SECP 2013). The Guidelines are intended to promote the responsible business conduct which supports the growth and development of society for the interest of public, and eliminate the adverse practices which affect the public sphere and ensure corporate transparency and accountability (National Voluntary Guidelines 2012). The Guidelines encourage the corporates to have a clearly defined CSR Policy approved and endorsed by their Board of Directors with priority areas which cover skill development, poverty alleviation health, education, infrastructure, anti-corruption, safety, environmental concerns and climate changes (Ibid:6). The Guidelines further espouse that the company is expected to allocate a certain percentage (about 1-2\%) of its profit or resources to be used for the implementation of CSR Policy it has designed. Moreover, the guidelines conclude by hoping that the companies shall pursue a policy of disclosure and reporting where it shall display the description and well as monetary information of CSR activities it has undertaken in each financial year.

\subsubsection{Companies Ordinance 1984}

It is pertinent to mention here another noteworthy legislation regarding setting up and functioning of companies in Pakistan. The Companies Ordinance, 1984 is the main statute that governs almost each and every aspect of companies and corporates. With as many as 514 sections, this is one of the exhaustive and extensive piece of legislation in the country. However, it is regretfully stated that not even a singly section hints about environment protection, community service, or other core principles of CSR.

\subsubsection{Codes of Conduct}

Moreover, the voluntary codes of conduct established by the companies themselves for various reasons also contribute to the literature and structure of CSR in the country. The companies tend to form a CSR policy not only for philanthropic purposes but also because it is likely to improve their image in the public, increase media coverage, boost employee engagement and attract and retain investors. However, the number of companies which have developed such voluntary CSR codes is not considerable and is well below desired or even satisfactory level.

\subsubsection{Contract Provisions}

Moreover, the provisions of Contract between companies and government also set out obligations to carry out CSR. Being established in contract, these obligations are contractually and legally mandated for the companies to fulfill in the area of environment and the societies living in areas where these companies operate. As far as it is necessary to for the well-being of economy of a country that the natural and mineral wealth be exploited for public weal, it is also imperative that welfare of the people residing in areas where these companies operate is not adversely affected and also that local community benefits from these activities. ${ }^{12}$

\subsubsection{SBP Regulations}

Under the State Bank of Pakistan, a number of sensible regulations were formed on the $31^{\text {st }}$ of January 2009. These regulations are directed at corporate banking and how CSR is to be taken into account respectively. These regulations are intended for the boards of directors and managers (Ahmed and Ahmad 2011).

\subsubsection{Case Law- Supreme Court of Pakistan}

Before we begin this heading, it is pertinent to mention the significance of case-law in Pakistan. Pakistan, being

\footnotetext{
${ }^{11}$ Clause 3 of SECP Guidelines for CSR uses the words 'Companies are encouraged to have a CSR Policy', which displays its voluntary and non-binding character.

${ }^{12}$ Const. P. 46 of 2013 Supreme Court of Pakistan, Titled Abdul Hakeem Khosa's Suo Moto Case (PLD 2014 SC 350)
} 
a country following Civil Legal System, lays great importance upon the precedents set by the courts in their decisions. There are two main reasons to discuss this decision in detail: 1) This case now serves on equal footing as a law could have done in enforcing CSR policies and provisions, 2) This is the first judgment of its kind and thus bears significance of forward step for stepping forward.

In 2013, Supreme Court gave a landmark decision related to CSR activities of multinational and local companies. The case related to the Oil and Gas Development Corporation Limited (OGDCL) which is a state enterprise, and more than 25 other companies, domestic and international, which were engaged in exploration and mining of oil and gas in various districts of the country. The brief facts of the case are presented below:

In an application submitted by a resident of Sanghar district, the applicant contended that Oil and Gas exploring companies in Sanghar are acting in violation of law and the terms and conditions of the petroleum concession agreement which they executed with the Government of Pakistan whereby they are bound to control environmental pollution, provide jobs and gas facility to local people... ${ }^{13}$ In the case, the Supreme Court observed that the conventional methods of seeking legal redress can be inadequate for people without sufficient means, especially when they face highly powerful companies and corporations (Ibid:5). The comments received from Director General Petroleum Concessions (DG PC) disclosed that the contractual obligations and commitments of Exploration and Petroleum (E\&P) companies had amounted to many millions of US dollars.

It is worth mentioning here that when a Petroleum Concession Agreement (PCA) is entered into between an E\&P and Government, the PCA contains conditions for the development, capacity building and environmental protection of the locality from where oil and gas are extracted. The PCA in its clauses requires that unskilled labour should be taken from the inhabitants of the area, while if available, rest of manpower should also be taken from the same area. It further requires that forest property shall not be damaged, and the licensees will strictly follow the environmental protection and pollution control laws and guidelines notified by the Government.

After receiving reports from various quarters, the Supreme Court of Pakistan concluded in its judgment that social welfare obligations imposed on E\&P Companies were not being followed and there was insufficient and ineffective monitoring and enforcement to ensure that such obligations are met. The Supreme Court also mentioned that DG PC was authorized to take enforcement action against any company if it was found not complying with the terms of permit, license, lease, agreement and/or the rules.

The Supreme Court after examining all the reports and listening to the parties ordered that DG PC shall solicit biannually reports from all E\&P Companies regarding their social welfare obligations. Moreover, it ordered DG $\mathrm{PC}$ to bring a report of estimated figures of royalties that are due on E\&P in lieu of obligations towards welfare of people and environment as per the terms of PCA. It also suggested that guidelines may be prepared by the Federal and Provincial Governments so that welfare obligations can be monitored and enforced, and expenditure of those funds can be examined in open and transparent manner.

In this case, it became quite evident that despite having no potential law about CSR, companies and concerned departments may be forced to perform their obligations as per contracts they have signed and by invoking jurisdiction of courts under Article 184 (3) of Constitution of Pakistan, 1973. ${ }^{14}$ This decision also works as a stepping stone for the future of CSR in Pakistan, since the local and international companies were declared responsible and liable for the activities carry out in any locality of Pakistan. Through the mention of terms and conditions of license of exploration, it made clear that the people of the locality where the company operates has a first right to jobs created by its working. This court case, besides emphasizing on the need of CSR and its value for the society, also pinpointed the loopholes which companies deliberately or unintentionally exploit and get away with obligations worth billions of dollars each year.

\section{CSR Practice of Corporations in Pakistan}

In this section, we shall analyze the CSR activities undertaken by different MNEs working in Pakistan. For the sake of sample, we have selected four Multi-National Companies operating in the country, which includes three foreign (two Chinese and one Non-Chinese) and one domestic corporation. We shall go through the official report which they have released following SECP Guidelines mentioned in the previous section. Furthermore, we shall discuss a report issued by US Department of State, wherein the state of CSR in Pakistan was explained and evaluated.

\footnotetext{
${ }^{13}$ Const. P. 46 of 2013 Supreme Court of Pakistan, Titled Abdul Hakeem Khosa'sSuo Moto Case (PLD 2014 SC 350) pp 3

${ }^{14}$ Under Article 184(3), the Supreme Court has the power to make an order on questions of public importance with reference to the enforcement of any of the Fundamental Rights.
} 


\subsection{CSR Activities of Zong}

The first case we have is of Zong Mobile Network, which is one of the five main network service providers in Pakistan. Zong is the Pakistani version of China Mobile, which is the largest network provider in the World. Zong started operating in 2008 in its current form and as of 2014, it has invested over 2 billion US dollars. Zong plans to invest another billion dollar in the coming 2-3 years, as was Minister of Information Technology Anusha Rehman quoted by Express Tribune (Azam Khan 2014). It is no beyond doubt that with such huge budget and investment, Zong represents China in Pakistan on the technology and information front. Now let us see if Zong is fulfilling its CSR or not, and if yes, to what extent.

Zong has been involved in CSR for quite a long time. However it was 2017, when for the first time, they have released their first CSR Report for the outgoing year. The Report which was available on the official website of Zong (CSR Report 2017) gave the details of CSR undertaken by the company during 2016. In the report, though the company has not mentioned or stated any financial figures to show the extent of CSR activities they had done, however, it has described in reasonable detail all projects which it undertook under the umbrella of CSR. We shall discuss them in brief in the next paragraphs which is actually a summary of the report.

Zong employed not only capital for CSR but also volunteered through its employees for creating a change and bringing about improvement in the society. Through its project called 'A New Hope', Zong volunteers at least 2,000 hours of its employees annually, and works in collaboration with partner organizations. Examples of volunteer work included volunteers spending a day with kids of SOS village in Islamabad, regular internet training at Mashal Model School and community mobilization.

During the floods from 2010-13, over 20 Million people were affected. Zong helped affected people during those hard times and provided them with temporary settlements, food, ration, medical aids etc. Zong's volunteers themselves distributed boxes of relief goods to aid over 4,000 affected families in the area.

In the health field, Zong collaborated with an initiative called 'doctHERs where through telemedicine clinics, health facilities are provided to the marginalized segments of society. Zong has regularly conducted Blood Donation drives through the country. Moreover, Zong is actively working in social fields to help the underprivileged factions of the community vis-à-vis widows, orphans, low income families and physically/mentally challenged individuals. However, not mentioned in the original report is a step taken by Zong and UNICEF Pakistan to fight polio in the country.

In the Education field, Zong has set up a 4G Internet Lab in Mashal Model School, 4G Research lab at Lahore University of Management Sciences, partnered with HEC to provide internet access to 100,000 students and with cooperation of Huawei, it has also established state-of-the-art GSM lab at NUST. The report quotes CEO Zong Liu Dianfeng, "I have a strong interest in making sure our services enable our youth, our universities and our students. We must ensure that our affordable products are accessible to students to pave the way for a bright future."

\subsection{CSR Activities of Pakistan State Oil}

Pakistan State Oil (PSO) is the largest fuel marketing company in Pakistan owned by the State of Pakistan Hussain 2015). Established in 1976 Pakistan State Oil is the major supplier of Oil products in Pakistan. It is the only public company in Pakistan the revenue of which crossed 1,000 billion rupees. PSO has, over the years, participated in CSR activities and it is quite renowned for its philanthropy. On its website, PSO has laid down its vision of CSR activities under the heading of sustainability. The company is committed to a number of causes revolving around and covering areas such as Education, Health, and Community Service, Women empowerment, welfare of Special children, Sports development and Flood and other natural disaster Relief Activities.

PSO, being a company related to oil and fuel, has a special focus on environment and its protection. PSO commits itself to the guidelines and rules of UN Global Compact. PSO joined UN Global Compact Community in June 2016. This step taken by the company shows its determination and resolves to make society a better place for the generations to come, by committing itself to the rules and regulations of CSR is the field of human rights, labor rights, environment, health and safety (Yu and Zia-ud-Din 2018).

In the field of Women Empowerment, PSO has been backing up a national NGO, Behbud Association (Welfare Association) which works in the area of reproductive health, education, professional training, and community development to encourage the neglected factions of the society to live a better and more productive life. PSO also cooperates with and helps out Rashid Memorial Welfare Organization which carried out Health, Education, vocational training, poverty alleviation, etc.

Pakistan State Oil has, on various occasions, provided relief facilities and services in case of a natural disaster 
like Earthquake or Flood in the country, or any part of it. After the Earthquake of 2013, which left people dead and many hundreds homeless, PSO provided the people of Balochistan with tents, mosquito nets, ration bags, mineral water and other necessities. During one of the worst floods of Pakistan's history in 2010, PSO once again stood up with the affected people and provided them cooked food and distributed relief items which included ration bags, tents, blankets and biscuits. Similarly, during monsoon rains in September 2011, PSO distributed ration bags and other necessities to more than 2000 people, while setting up 3 medical camps wherein medicines were distributed free.

Pakistan State Oil is always keen to support initiatives taken for Special Children. It has contributed for the Institute of Special Children in Quetta to improve their equipment so that Education to the special children can be imparted effectively (Shahid 2012). Other than the institute in Quetta, PSO also supports monetarily Pakistan National Institute for the deaf children of Kamoke City. For a similar cause to help the special children of the society, PSO has supported financially Munir Arshad Memorial Trust, and Family Education Services Foundation ${ }^{15}$.

\subsection{CSR Activities of Unilever}

Another Company working in Pakistan which actively follows CSR guidelines is Unilever Corporation. Unilever Corporation is a Dutch company which set up its offices in Pakistan in 1948. Unilever Corporation is one of the biggest multi-national companies working in Pakistan which has announced on $19^{\text {th }}$ March 2018 to invest over 120 Million US dollars (UNILEVER 2018). Unilever states on its website, 'Our vision is a new way of doing business - one that delivers growth by serving society and the planet'. Unilever has participated in various CSR activities and has continuously provided them in its report as well. Few of them are mentioned below for ready reference.

Unilever has set three main targets to achieve by 2020. The three targets i.e. Health, Environment, Better Livelihood- are further divided into sub-categories for more specific goals. In the category of health, Unilever aims to reduce diarrheal and respiratory disease through hand-washing, provide safe drinking water, improve access to sanitation and improve oral health. As per details, last target mentioned herein has already been achieved while 538 million people have been reached till the end of 2016 in safe drinking water target. Moreover, Unilever aims to improve nutrition by reducing salt levels and saturated fat.

In the area of environment, Unilever aims to halve the greenhouse gas impact of their products across the lifecycle by 2030, and by $2020, \mathrm{CO}_{2}$ emissions from energy of factories will be at or below 2008 levels despite significantly higher volume. As per their website, greenhouse gas impact per consumer use has increased by around $8 \%$ since 2010 while a $43 \%$ reduction has been achieved in $\mathrm{CO} 2$ from energy per tons of production since 2008 .

To increase the living standards of the people in general and its employees in particular, Unilever resolves to Implement UN Guiding Principles on Business and Human Rights, develop a framework for fair compensation, improve employee health, nutrition and well-being, and reduce workplace injuries and accidents. For women empowerment, Unilever aims to enable 5 million women by 2020 by expanding opportunities for women, promoting safety for women in communities and enhancing access to training and skills.

\subsection{CSR Activities of Huawei}

Huawei is big giant Smartphone producing company of China which has businesses spread over all the six continents. In 2012, it became the largest company to produce telecommunication equipment in the world surpassing Ericsson (The Economist 2012) and in 2017, it crossed Apple in the Smartphone industry to become the world $2^{\text {nd }}$ Smartphone producer after Samsung (Eyerys 2017). Huawei is also one of the most popular Smartphone producers and suppliers in Pakistan. Let us now take a look at CSR initiatives taken by Huawei.

Huawei is committed to the social contributions and has annually produced the report of CSR activities. To take an example, we shall be looking at the report of 2016 available on their website (Huawei 2016). This report refers to the CSR activities taken worldwide by Huawei. However, we shall restrict ourselves to the steps taken in Pakistan by Huawei.

Huawei runs a Global Green Recycling Program, which is aimed to fulfill its extended producer responsibility by handling of scrapped mobile phones, tablets, and other electronic products. By recycling of old and useless

\footnotetext{
${ }^{15}$ Family Education Services Foundation is a non-profit educational organization which operates in Karachi. FESF has established a school for the Deaf in Karachi as well as two vocational training centers for Deaf students; one in Karachi which has been running for the past 16 years, and another in Lahore which was opened 12 years ago.
} 
phone and other devices, Huawei ensures that the scrapped items are properly processed in an environmentally responsible manner, which results in reduction of environment pollution. Huawei has setup at 10 recycling stations in Pakistan to achieve this target.

As far educational activities are concerned, Huawei organized global ICT competition in National University of Science and Technology (NUST). In September 2017, Huawei Company presented stationary packs, water dispensers and microwave ovens to ten different schools and three hospitals (which included Shifa International Hospital, PIMS) (TNS World 2017). As mentioned above, Huawei and Zong established state-of-the-art GSM laboratories and training centers at National University of Science and Technology (NUST) and University of Engineering and Technology (UET). With UET, Huawei has partnered now since 2002, when Huawei provided telecom equipment for a joint R\&D and training center that was expanded in 2007. The center has trained approximately 5,000 local engineers and students till date (Pro-Pakistani 2017).

At the World Economic Meeting held in January 2017, Huawei signed 'The Compact for Responsive and Responsible Leadership' as part of its loyalty and resolve to sustainable growth and CSR. "We will ensure that our company's strategic goals are aligned with the long-full term goals of society as a whole," said Madam Sun Yafang, Chairwoman of Huawei (Ibid). Further exhibiting its determination to finding renewable energy solutions, Huawei Pakistan has introduced solar-wind hybrid solutions and solar-diesel hybrid solutions for mobile communication sites.

\subsection{Survey Conducted by Pakistan Institute of Corporate Governance}

In 2013, Pakistan Institute of Corporate Governance conducted a survey (PICG 2013) in which more than 50 companies were asked a set of eight questions related to CSR. The results of this survey are important because they give us an insight into the overall understanding of companies working in Pakistan about CSR and its values.

$62 \%$ of participants replied to first question- if they had a sustainable development strategy- in affirmative. An overwhelming 90 percent of participants informed that their companies considered environment protection an important part of corporate culture. All the surveyed companies agreed that sustainability and CSR enhance a company's brand image and reputation. When asked if their organization had a policy of evaluating the environmental impact of investments, 61 percent replied that they did have some form of policy to estimate the environmental impacts.

Almost 90 percent of the respondents supported the concept of compulsory Sustainability Reporting. Almost 78 percent respondents were in favor of engaging assurance providers who can review Corporate Responsibility programs. Almost 90 percent of the respondents agreed to having a set of Key Performance Indicators since having measurable data to substantiate facts and figures is essential to meaningful sustainability reporting (Ibid:2).

The purpose to mention the results of this survey was to show that the sense of CSR is developing in Pakistan, though slowly and gradually. The companies are mostly aware of the fact that they are expected to perform CSR activities for the improvement of people, its employees and the environment. However, the pursuit of these ideals is yet a little far from reality when we talk about all the companies.

U.S. Department of State published a report in 2015, under the title '2015 Investment Climate Statement Pakistan'. The report was prepared by Bureau of Economic and Business Affairs wherein a summary about the situation and suitability of Pakistan for foreign investments was explained. Paragraph number 11 and 12 of the report are relevant to our topic. The report concludes that State Owned Enterprises (SOEs) of Pakistan, which represent one-third of stock market in the country, do not follow OECD guidelines for their corporate governance. However, it mentioned that in recent years, there is an increase in awareness among the consumers and producers when it comes to CSR. The report concludes that some international and domestic enterprises pursue the prevalent and accepted CSR guidelines and through various media including social media, advertise their campaigns. However, in Pakistan, CSR is usually considered equivalent with corporate philanthropy and thus, it can be said that CSR in Pakistan is still its infant state. It rightly concludes that most of the companies in Pakistan do not follow CSR mainly because they do not feel any danger if they do not adopt such activities, which we shall see in the following paragraphs in a Supreme Court case related to CSR.

\section{Problems and Solutions}

In this part, we shall summarize our findings, and make recommendations if necessary, for the improvement of state of CSR in Pakistan. But before we move on to that part, we shall first look at the availability of data on which we have relied, so that the conclusion and findings we draw can be understood accordingly. 


\subsection{Availability of Data}

We have in previous section discussed the CSR activities of four companies working in Pakistan, three of which were foreign MNEs. It is pertinent to mention here that the data and information discussed in this paper are retrieved mostly from the websites and reports published by the companies themselves. The evaluation from any independent third party is almost non-existent. So, in other words, we have to rely on the data reported by companies. Even most of the articles and papers which we consulted during the course of carrying out this research depended upon such source of information.

Another important fact that must be kept in mind is that the companies we have mentioned in our study are neither the only ones nor they represent the prevalent state of CSR in Pakistan. They were taken to take some case studies. There is a satisfactory number CSR-abiding corporations in Pakistan (Pakistan Observer 2017) and seminars and conferences to support and propagate the idea of CSR is on the rise (Pakistan Observer 2017a). An organization with the name of Corporate Social Responsibility Center Pakistan (CSRCP) which believes that companies should reveal their performance or the reasons why they don't has published yearly sustainability and integrated reports of a number of companies in Pakistan. This database shows that major companies in Pakistan are indeed concerned for one reason or another in fulfilling their social responsibilities.

However, having said that, there is a great number of those companies too which do not follow CSR activities or equate it more with philanthropy rather than considering them contractual and legal obligations. The data related to CSR is therefore inadequate and mostly does not sourced from any independent third party. Keeping in view these limitations, we shall arrive at our conclusion after discussing our findings.

\subsection{Problems in CSR in Pakistan}

Such is the state of CSR in Pakistan that when you are about to conclude that it is non-existent in the country, it starts to appear everywhere, and when you start to believe its ubiquity, it seems in its infant stages. In the beginning of research, there was a presupposition that laws relating to CSR activities did not exist in Pakistan. However, over the course of this research, it was found that from labor laws to environmental laws, from voluntary guidelines to mandatory contractual obligations, CSR laws do exist in Pakistan in one form or another. At the same time, we find that a lot of work has yet to be done in this field in Pakistan as CSR is mostly equated with corporate philanthropy.

However, it is appropriate to mention here an Indian legislation which came into force in 2013. The Companies Act, 2013 of India requires any company with revenues over 10 billion rupees (131 million dollars approx.) to spend 2 percent of their profit on CSR activities (Noreen 2017). In the process thereof, India became the first country in the world to make it mandatory for countries to spend some part of their profit for philanthropic purposes. No such law, however, exists in Pakistan and is not even likely to come into being for next two decades at least. Absence of such law is, nevertheless, not a major hindrance in proper pursuance and implementation of CSR ideals. It is rather lack of seriousness on the part of enterprises and absence of enforcement on part of government coupled with want of awareness in general public about CSR which together result in low ratio of CSR activities in Pakistan as compared to developed and developing nations.

Most of the companies are not aware of the CSR and its concepts. The small and medium scale businesses are mostly found not to adhere any CSR activities and they do not have any department dedicated to CSR activities. However, multinational companies and other large scale local companies have been found to be more cohesive to the Corporate Social Responsibility Practices. A number of such companies do have specific departments who are tasked with carrying out these practices. They publish and promote their CSR activities through local newspaper and their website and some of them publish yearly reports too.

Moreover, we found that general public is not aware of this concept. The result of lack of awareness is that companies do not pay much attention to CSR and are not concerned to carry them out mostly because they know that people are indifferent and oblivious to this area of corporate sector. The absence of awareness among general public of basic human rights, citizen rights, and consumer rights results in lack of questioning by the public and mass media over violations of the above rights (Ahmed and Ahmad 2011).

During the research, we found that labor laws have a substantial presence in Pakistan, with clearly defined guidelines, recommendations and obligations for the companies and workplaces to follow to ensure the protection of rights of their employees. These labor laws are quite comprehensive and are complemented by governmental enforcement organizations and special labor courts. These courts are fully competent to try offences related to employees and labor and can take cognizance of any such matter related to companies and employees. 
Other than these labor laws, the Constitution of Pakistan, 1973 in its fundamental rights as well as article 37 makes sure the existence of certain core principles of CSR such as labor rights, rights to association, abolition of child labor etc. Moreover, the article 184 (3) of the Constitution empowers the Supreme Court to take cognizance of any matter related to public importance. This article is significant because it was and can be used to hold local and national companies accountable for their lack of interest and activity in CSR. ${ }^{16}$

In the field of CSR spending on the infrastructure and/or the betterment of the locality where these MNEs operate, we found that some government agencies publishing certain guidelines to be followed by the companies. To begin with, we have the CSR guidelines produced as well as revised periodically by the Securities Exchange Commission of Pakistan (SECP). The guidelines are as previously mentioned not binding and companies are encouraged, not bound to follow them. These guidelines have laid down a basic structure of carrying out of CSR activities in the country. This organization also released a Code of Corporate Governance which requires the Board of Directors of any company to take measures to avoid harmful effects of its activities on the environment, and to ensure the implementation of labor and other relevant laws of the country in respect of activities of its organization.

However, if there is something concrete and through which companies can be held accountable, it is the contract which they sign when they are granted license to work in the country. The provisions of these contracts are legally binding upon these companies to follow since they are the part of the contract they have willfully signed. Nonetheless, it has been seen that most of the companies do not follow these provisions and the governmental organizations which are entrusted with the task of ensuring that these regulations are fulfilled and implemented in their true letter and spirit.

\subsection{Solutions}

After going through the data available in CSR activities in Pakistan, certain recommendations are hereafter put forward in order to considerably enhance and properly implement CSR in the country. Since our main emphasis had remained over legal and contractual obligation over corporations to fulfill their CSR opportunity, our recommendations shall also involve and cover the legal aspects more than any others. Moreover, only those recommendations are placed here which are adjudged and considered to be practical, realistic and pragmatic.

In order to streamline all the CSR activities, companies registered or licensed to operate in the country should be bound to disclose their CSR activities periodically (preferably annually). This can be made compulsory by adding it either in legislation or by enforcing the contract provisions which already contain such provisions more often than not.

The government should, where it has not, include such provisions in contracts signed with all corporations, whether local or foreign, or in the terms of grant of license to operate in the country. The concerned department, like department of Petroleum Concessions for E\&P companies, should make sure that such provisions are properly and duly followed and implemented by the enterprises. In cases of negligence or omission to perform those activities, the concerned department must take strict actions against the disobeying companies.

The Companies Act of Pakistan must be amended so as to include a chapter especially on CSR activities. Even though legislation is of a lesser problem, and implementation is the key to this issue, the presence of a strong law shall make these activities to evolve more quickly and in a better shape.

It is the need of the hour that awareness campaigns must be runs on NGO as well as Governmental level to increase the knowledge and information among the masses. These campaigns include seminars, conferences, workshops and publications etc. If average general public awareness increases, it will lead to formation of voluntary associations among public, which can act as pressure groups against the corporations to follow the CSR concepts and activities.

The corporations need to understand that CSR is different from Corporate Philanthropy. Corporate Philanthropy is more of voluntary in nature and depends on the companies' will to carry on these activities, and it is similar charity works done by individuals. However, CSR is more of a social and moral obligation, which companies carry with themselves towards the community and people where they operate. CSR has the ability to make impacts in different fields of life such as rural development, community empowerment, health, education, awareness about rights and duties, creating more business opportunities and the development of infrastructure (Ahmed and Ahmad 2011).

Moreover, since CSR as seen in previous paragraph can address a number of areas from health, education,

${ }^{16}$ Const. P. 46 of 2013 Supreme Court of Pakistan, Titled Abdul Hakeem Khosa's Suo Moto Case (PLD 2014 SC 350) 
poverty alleviation, unemployment to infrastructure, empowerment and business opportunities, the areas where the need is most must be identified. This must be done at the governmental level and must be coordinated and conveyed to the companies, so that maximum advantage can be gained from CSR activities. In case otherwise, mostly companies will continue spending money on activities which generate public goodwill rather than addressing public issues and problems. If Enterprises spend the money allocated to CSR activities on well-identified areas, the living standard of the people can be elevated by providing them amenities and facilities. A country where a considerable population does not have access to clean water, health facilities, education and other basic needs, large-scale companies must play their roles in the form of CSR, and Government must identify and specify such areas where major work is to be done.

\section{Conclusion}

Such is the legal state of CSR in Pakistan that conducting a study on CSR in legal perspective appears to be more of a social sciences' research. This is partly because of the fact that CSR is more closely related to social aspects rather than legal side (because of its non-binding nature) and partly because CSR is Pakistan is still in its infant stages. With government indifferent and unconcerned attitude towards CSR, the concept remains more attached with Corporate Philanthropy.

From all the discussions we had above, it can be safely concluded that CSR, though still in its early stages, is growing gradually in Pakistan. However, the pace of the growth needs to be increased in which active role can be played by the government and NGOs. If CSR is carried out properly in Pakistan, many areas so far neglected or unaddressed in the public domain can be improved.

The legal side of CSR is almost non-existent in the country. Though there are certain departments concerned with carving out the rules of procedure for the implementation of CSR, no department was found to be properly urging and pushing corporates to follow those rules. They appear to be a formality to be done rather than a target to be achieved. It was evident in the Supreme Court Case we discussed above that even the mainstream departments in Petroleum Ministry did not bother to force the companies to follow and fulfill the contractual obligations of CSR despite being clearly mentioned in the grant of license and terms of contract. The government must pay heed and attention to this facet of the Corporates especially the big industries.

As far as legal remedies are concerned, it has to be seen in three categories which are remedies available to general public, employees and to the Governmental Departments. The general public, as we witnessed in the CSR case of Supreme Court of Pakistan, can approach the courts under the ambit of Article 184 (3) of the Constitution to take notice of irregularities being committed by Corporations and to direct them to indemnify the results of those omissions or commissions. Moreover, the employees of these Corporations can take their employers to the court if they find them violating the labour laws of the country. The governmental departments especially the ones which grant license to the organizations to operate in the country can revoke their license if they do not fulfill their obligations under the contracts signed to get such license. They can also, on the basis of terms of these contracts, approach the court to hold these MNEs responsible for non-fulfillment of contractual obligations which include CSR activities too.

\section{References}

Ahmed, A., \& Ahmad, I. (2011). Corporate Conscience: CSR in Pakistan-a Study. Prakruthi.

Alavi, H. et al. (2016). Corporate social responsibility and self-reulation. MM Science Journal, 1121. https://doi.org/10.17973/MMSJ.2016_10_201681

Bantekas, I. (2004). Corporate social responsibility in international law. BU Int'l LJ, 22, 309.

Board of Investment (BOI), Prime Minister's Office Official. Retrieved July 27, 2019, from http://boi.gov.pk/ForeignInvestmentinPakistan.aspx

Brommes, V. (2017). Who Invests Wins: Leveraging Corporate Social Responsibility for CEOs, Investors and Policymakers to create 'TripleWins'.

Chmielecki, M. (2014). Key drivers of corporate social responsibility in Asia.

Cochran, P. L. (2007). The evolution of corporate social responsibility. Business horizons, 50(6), 449-454. https://doi.org/10.1016/j.bushor.2007.06.004

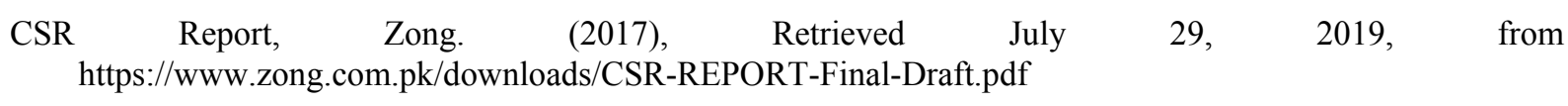


Dlubatz, S. (2016). Confucianism, Business Ethics and Corporate Social Responsibility: Its Implication and Interconnection for Modern Businesses, Business Management and Business Strategy in Japan and China. Master's diss, Universitatwien.

Eyerys "Huawei Sells More Smartphones Than Apple: Becoming The Second Largest Smartphone Brand After Samsung" 6 September 2017. Retrieved July 29, 2019, from https://www.eyerys.com/articles/timeline/huawei-sells-more-smartphones-apple?page $=5$

Gordon, K. (2001). The OECD guidelines and other corporate responsibility instruments.

Hameed, S. K. (2010). Corporate social responsibility (CSR) theory and practice in Pakistan.

Hasan, S. (2 May 2015). At the helm: EngroElengy'sHaque takes up reins of Pakistan State Oil. The Express Tribune (newspaper). Retrieved July 29, 2019, from https://tribune.com.pk/story/879417/at-the-helm-engro-elengys-haque-takes-up-reins-of-pso/

HUAWEI. (2016). Connecting the Future, Sustainability Report. Retrieved July 28, 2019, from http://www-file.huawei.com/-/media/CORPORATE/PDF/Sustainability/2016-Huawei-sustainability-reporten-v2.pdf?la=en

ILO. (2017). Enterprises, Concerning Multinational. "Tripartite Declaration Of Principles Concerning Multinational Enterprises And Social Policy."

Khan, A. (2018). Inflow: Zong to make licence payment in dollars, Express Tribune, April 27, 2018. Retrieved July 29, 2019, from https://tribune.com.pk/story/700716/inflow-zong-to-make-licence-payment-in-dollars/

Muchlinski, P. (2001). Corporations in international litigation: problems of jurisdiction and the United Kingdom asbestos cases. International \& Comparative Law Quarterly, 50(1), 1-25. https://doi.org/10.1093/iclq/50.1.1

NatachaWexels-Riser, National Labour Law Profile: Islamic Republic of Pakistan. Retrieved July 26, 2019, from http://www.ilo.org/ifpdial/information-resources/national-labour-law-profiles/WCMS_158916/lang--en/ind ex.htm

National Voluntary Guidelines: Creating a Conducive Policy Environment for responsible business and responsible Investment in India. (2012). Retrieved July 25, 2019, from http://sblf.sustainabilityoutlook.in/file_space/NVG\%20Genesis\%20Document.pdf

Nemoto Rechden, E. (2013). Implementing Corporate Social Responsibility (CSR): Assessing Current CSR Status at Haldex. IIIEE Master thesis.

OECD Guidelines for Multinational Enterprises, 2008. Retrieved July 27, 2019, from https://www.oecd.org/corporate/mne/1922428.pdf

OECD, 2011 Update of the OECD Guidelines for Multinationals Enterprises. Retrieved July 27, 2019, from http://www.oecd.org/investment/guidelinesformultinationalenterprises/2011update.htm

Ohlrich, N. (2017). Mandatory Corporate Social Responsibility in India: How Is It Working? Non Profit Quarterly. $\quad$ Retrieved July $\quad 30, \quad 2019, \quad$ from https://nonprofitquarterly.org/2017/02/17/mandatory-corporate-social-responsibility-india-working/

Pakistan Center for Philanthropy. (2016). The State of Individual Philanthropy in Pakistan.

Pakistan Centre for Philanthropy (PCP). (2006). Corporate Philanthropy in Pakistan: A Survey of Public Listed Companies.

Pakistan Institute of Corporate Governance (PICG) Survey: Conference on Sustainability Reporting, Corporate Social Responsibility and Governance, January 22, 2013. Retrieved July 30, 2019, from http://picg.org.pk/wp-content/uploads/2015/11/CSR-Sustainability-Practices-in-Pakistan-2013.pdf

Pakistan Observer(a), Int'l CSR summit awards 2017 on Jan $19^{\text {th }}$, Pakistan Observer, 10 January 2017. Retrieved July 30, 2019, from https://pakobserver.net/intl-csr-summit-awards-2017-on-jan-19th/

Pakistan Observer, 55 companies to receive CSR Awards, Pakistan Observer, 20 January 2017. Retrieved July 30, 2019, from https://pakobserver.net/55-companies-to-receive-csr-awards/

Petrick, J. A., \& Scherer, R. F. (2003). The Enron scandal and the neglect of management integrity capacity. American Journal of Business, 18(1), 37-50. https://doi.org/10.1108/19355181200300003 
ProPakistani, Huawei Pakistan Collaborates to Build a Sustainable, Better and Connected World, Propakistani. Retrieved July $30, \quad 2019, \quad$ from https://propakistani.pk/2017/07/26/huawei-pakistan-collaborates-build-sustainable-better-connected-world/

Rius, A. (2016). Globalization Impact on CSR Issues. Retrieved July 28, 2019, from https://www.linkedin.com/pulse/globalisation-impact-csr-issues-alex-rius/

Sajjad, A., \& Eweje, G. (2014). Corporate social responsibility in Pakistan: current trends and future directions. Corporate social responsibility and sustainability: Emerging trends in developing economies. Emerald Group Publishing Limited: 163-187. https://doi.org/10.1108/S2043-905920140000008010

SECP. (Feb 16, 2013). Retrieved July 25, 2019, from https://www.secp.gov.pk/document/voluntary-guidelines-for-csr-2013/?wpdmdl=12989

Shahid, K. K. (2012). Corporate Social Responsibility in Pakistan. Pakistan Today (Newspaper), 15 January 2012, Retrieved July 29, 2019, from https://www.pakistantoday.com.pk/2012/01/15/corporate-social-responsibility-in-pakistan/

ShuHong, Y., \& Zia-ud-Din, M. (2017). Questioni di diritto del lavoro in Pakistan: il fondamento storico della legislazione lavoristica e delle associazioni sindacali. Labour \& Law Issues, 3(2), 21-54.

Sony Corporation. (2017). CSR Report of Sony Corporation. Retrieved July 27, 2019, from https://www.sony.net/SonyInfo/csr_report/ncrtrb000000gclx-att/CSR2017E_PDF_all_e.pdf

The Companies Ordinance, 1984.

The Constitution of the Islamic Republic of Pakistan, 1973.

The Economist "Who's afraid of Huawei?" The Economist. 3 August 2012. Retrieved July 29, 2019, from https://www.economist.com/node/21559922

The Factories Act 1934.

TNS World, Huawei continues its Corporate Social Responsibility activities in Pakistan. Retrieved July 28, 2019, from https://tns.world/huawei-continues-its-corporate-social-responsibility-activities-in-pakistan/

Unilever. (2018). Unilever announces USD 120 Million investment in Pakistan. Press Release. Retrieved July 29, 2019, from https://www.unilever.pk/news/press-releases/2018/unilever-announces-usd-120-million-investment-in-pakis $\tan . h t m l$

Waheed, A. (2005). Corporate social responsibility in Pakistan and a strategy for implementation. Securities and Exchange Commission of Pakistan.

Williams, G., \& Zinkin, J. (2010). Islam and CSR: A study of the compatibility between the tenets of Islam and the UN Global Compact. Journal of Business Ethics, 91(4), 519-533. https://doi.org/10.1007/s10551-009-0097-x

Yu, S., \& Zia-ud-Din, M. (2018). International Trade Agreements and Their Relation to Core Labor Standards. J. Pol. \& L., 11, 33. https://doi.org/10.5539/jpl.v11n3p33

\section{Copyrights}

Copyright for this article is retained by the author(s), with first publication rights granted to the journal.

This is an open-access article distributed under the terms and conditions of the Creative Commons Attribution license (http://creativecommons.org/licenses/by/4.0/). 